\title{
不感帯機構付きオイルダンパーを用いた免震建物の地震応答性状 SEISMIC RESPONSE CHARACTERISTICS OF SEISMICALLY ISOLATED BUILDING
WITH DEAD ZONE MECHANISM CONNECTED TO OIL DAMPER
}

\author{
谷地畧 和夫*1, 鈴木 彰*2, 齋藤雄 太 ${ }^{* 3}$, 得 能 将紀 ${ }^{* 2}$, 小林正 人*4 \\ Kazuo YACHIUNE, Akira SUZUKI, Yuta SAITO, \\ Masaki TOKUNO and Masahito KOBAYASHI
}

\begin{abstract}
In recent years, there is concern about the occurrence of extreme ground motions that greatly exceed the amplitude levels and durations expected in conventional design level. Therefore, seismically isolated buildings are required to secure the seismic isolation performance for small earthquakes and to suppress the excessive displacement of seismic isolation layer for extreme ground motions. In this paper, we analyze the seismic response of seismically isolated buildings with the dead zone mechanism connected to oil damper to understand the response characteristics.
\end{abstract}

Keywords : Seismic isolation, Dead zone mechanism, Extreme ground motion, Seismic response characteristic, Automatic returning to original position, Evaluation of habitability 免震，不感帯機構，大振幅地震動，地震応答性状，原点自動復州，居住性能評価

\section{1.はじめに}

近年，従来の設計で想定される振幅レベルや継続時間を大きく上 回る大振幅地震動の発生が懸念されており, 免震建物においては, 大振幅地震動発生時に免震層変位が過大になり, 擁壁衝突を起こす 可能性が考えられる。対策として, ダンパーの増設やクリアランス の確保などが挙げられるが, ダンパーの過度な増設は, 絶対加速度 の増加を招くため免震性能の低下に繋がる恐れがあり, また, 都市 部の密集地域ではクリアランスの確保も難しいのが現状である。そ こで近年の免震建物では, Fig.1 に示すような中小地震動に対する 免震性能を確保しつつ, 大振幅地震動に対寸る免震層の過大变位も 抑制可能な, 絶対加速度と変位のトレードオフ関係を同時に解決す

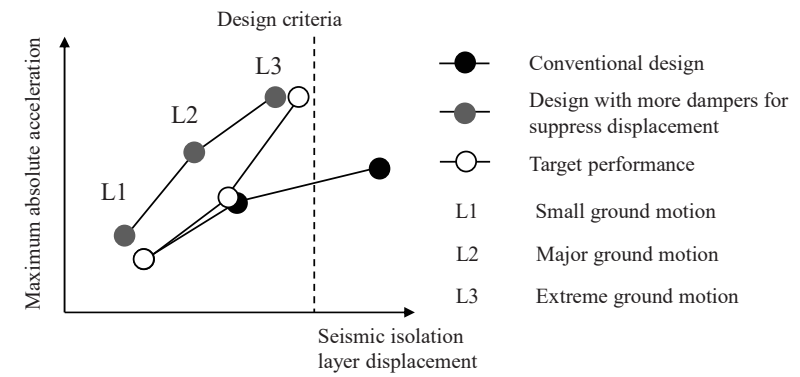

Fig.1 Relation of acceleration of superstructure and displacement of seismic isolation layer
る性能が求められている。なお，L1，L2 地震時の絶対加速度増加を 防ぐため, 一定の振幅未満では，ダンパーが減衰力を発揮しないこ とを考慮して，L3 地震時にやや応答変位が増えると予測した。

以上の要求を満たす有効な手段の一つとして, オイルダンパーの 減衰係数を可変制御する電磁切換式のセミアクティブ免震システム が開発されている。多くは最適制御理論に基づいた制御方法例えば 1$)$ であるが，中には免震層の変形のみを制御パラメータとした簡便な 制御則であるMinMax 制御を用いた方法 2)も提案されている。

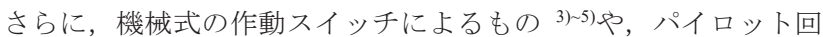
路の圧力を用いた切り替え回路を組み込み，伸側・縮側で個別に減 衰係数を切り替えることも可能なバイフロー式のもの ${ }^{6}$ ，免震層の 応答変位あるいは応答速度に応じて減衰力を切り替えることができ るダンパー7など，セミアクティブ免震システムよりも安価で動作 信頼性の高いパッシブ型ダンパーの開発が盛んに行われている。

一方, 筆者らは, Fig.2 に示す不感帯機構 8) 10)を提案している。不 感帯機構は, 既存のオイルダンパーに接続する付属装置である。本 機構は免震層変位が不感帯幅以下の場合（中小地震レベル）で減衰 力を発生させず，より高い免震性能を確保し，免震層変位がそれ以 上の場合（大地震レベル以上）で減衰力を発生させ，大地震時の免 震性能の確保およびそれを超える大振幅地震動による過大変位を抑 制する仕組みである。さらに，本機構の特徴の一つとして，地震終 了時（無負荷時）にロッドを原点位置まで自動復帰させるスプリン 


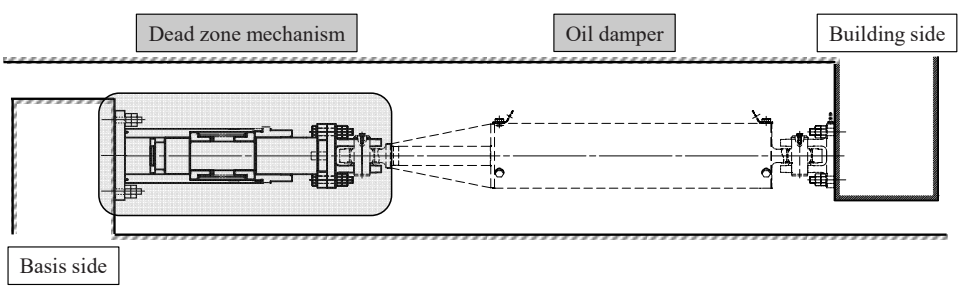

Fig.2 Dead zone mechanism

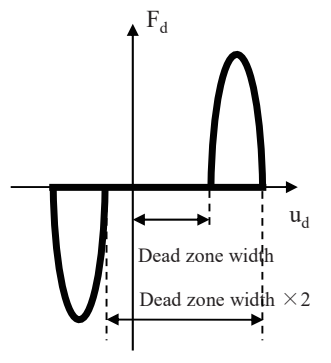

Fig.4 Restoring characteristics of oil

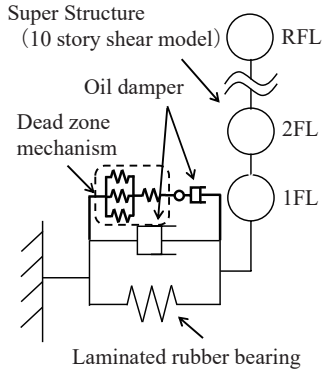

Fig.5 Analysis model damper attached dead zone mechanism

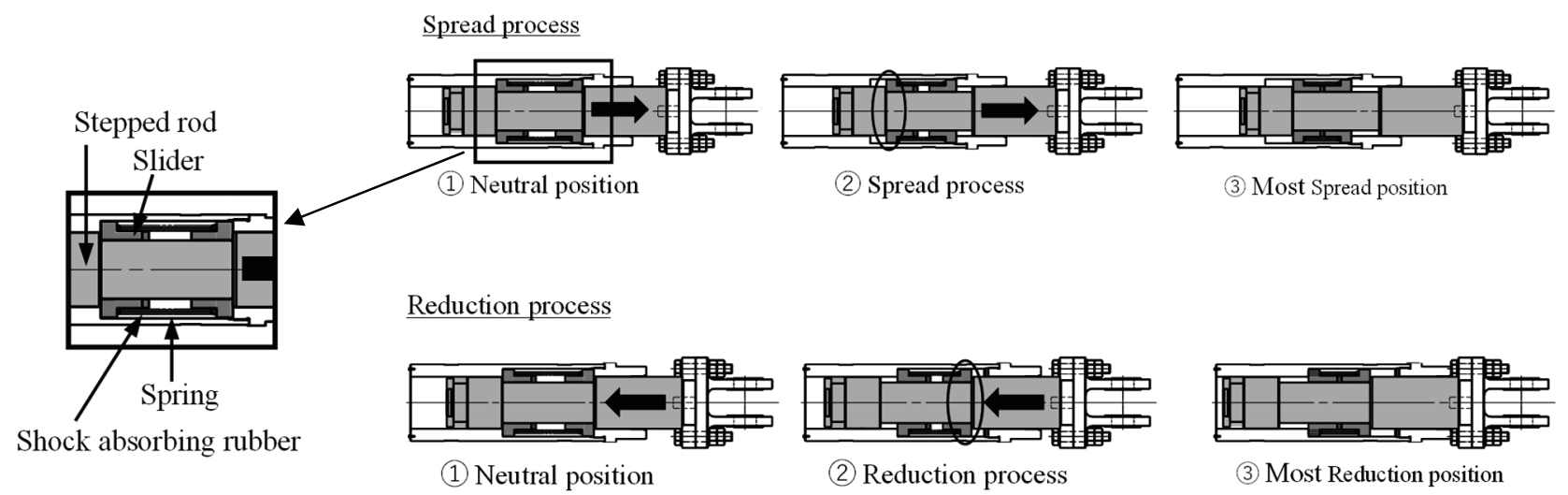

Fig.3 Dead zone mechanisim behavior

グを搭載しており, 維持管理の面において有用性が高いことが挙げ られる。また, 本機構は従来のパッシブ型ダンパーと比較して, オ イルダンパーの加工が不要なため, 既製品を使用することでコスト を抑えることが可能である。さらに, 既存建物への適用も可能とな る。なお, 不感帯機構の部材長は $1,300 \mathrm{~mm}$ 程度を想定している。

不感帯機構の具体的な挙動を Fig. 3 に示す。本機構が伸張工程に ある場合，段付になっているロッドの丸部がスライダーを押し，ス ライダーはスプリングを縮めながら伸び方向へ進む (1)(2)。スライ ダーが反対側へ到達すると接続されたオイルダンパーが作動し, 減 衰力を発生する (3))。スライダーの片側には, スライダー同士の接 触による衝撃を緩和するための緩衝ゴムが設けられている。緩衝ゴ ムは耐候性に優れたクロロプレンゴムを加硫成形したものであり, スライダーは一般的な JIS 規格鋼材を研磨したものを想定している。 圧縮工程にある場合も同様の考え方である。上述の挙動により, 本 機構に接続するオイルダンパーは, Fig.4 のような復元力特性となる。 本報では, 不感帯機構を用いた免震建物に対して, 地震応答解析を 行い, 応答性状について把握する。

\section{2. 解析モデルおよび入力地震動}

\section{1 免震建物モデル}

本解析に用いる解析モデルの概要を Fig.5 に, 解析モデルの諸元 を Table1 に示す。上部構造は高次モードの影響を十分に考慮するた めに 10 質点系等価せん断モデルとする。各層の質量を $1000 t$, 上部 構造の剛性は最下層に対して最上層の值が $1 / 2$ となる台形分布とし, 免震層固定時の 1 次固有周期 $T_{s}$ が $0.5,1.0,1.5,2.0$ 秒となるよう に水平剛性を決定する。減衰は免震層固定時の上部構造の 1 次固有
Table1 Analysis model and parameters

\begin{tabular}{|c|c|}
\hline Analysis model & 10 -story shear model \\
\hline Mass distribution & Each $1,000[\mathrm{t}]$ \\
\hline Stiffness distribution & $1 / 2$ ratio trapezoid \\
\hline Natural period $T_{s}$ & $0.5,1.0,1.5,2.0[\mathrm{~s}]$ \\
\hline Restoring characteristics & Linear $(\mathrm{h}=2 \%)$ \\
\hline $\begin{array}{c}\text { Restoring characteristics of } \\
\text { isolation devices }\end{array}$ & $\begin{array}{c}\text { Isolator : Bilinear } \\
\text { Damper : Bilinear }\end{array}$ \\
\hline Sesimic isolation period $T_{f}$ & $4.0[\mathrm{~s}]$ \\
\hline Dead zone width $[\mathrm{cm}]$ & $5,10,15,20,25$ \\
\hline
\end{tabular}

※old type indicates the basic case.

周期に対して $2 \%$ の剛性比例型減衰とする。また， せん断ばねの復 元力特性は弾性とする。

免震層は，オイルダンパーを用いた本機構の特徵を明確にするた め, 天然ゴム系積層ゴム (ゴム外径 $\Phi 800$, ゴム総厚 $156 \mathrm{~mm}, 2$ 次 形状係数 $S_{2}=5.1$ を想定）とオイルダンパーの組み合わせとする。 積層ゴムの復元力特性は, ハードニング特性を考慮したバイリニア 型とし, 積層ゴムのせん断歪が $250 \%(39 \mathrm{~cm})$ から 1 次剛性の 3 倍 の剛性を有するものとする ${ }^{11}$ 。。免震層の初期剛性 $k_{1}$ は, 免震周期 $T_{f}$ および建物質量 $M$ を定め, 式(1)より算定する。

$$
k_{1}=4 \pi^{2} M / T_{f}^{2}
$$

また, オイルダンパーの減衰力特性は速度依存のバイリニア型と ᄂ, 1 次減衰係数 $C_{1}=2.5 \mathrm{kN} \cdot \mathrm{s} / \mathrm{mm}, 2$ 次減衰係数 $C_{2}=0.17 \mathrm{kN} \cdot \mathrm{s} / \mathrm{mm}$, リリーフ荷重 $800 \mathrm{kN}$ とする。

解析に用いるオイルダンパーの基数は, L2 地震動に対して適切な 減衰量のモデル（以下， ベースモデルと称す）を設定し，後述の L3 地震動時の免震層変位を想定するクリアランス $60 \mathrm{~cm}$ 以内に抑える 
ため, ベースモデルに対して不感帯機構付きオイルダンパーを追加 するものとする。なお，幅広い振幅範囲を制御することを目的とす るため, 不感帯機構付きオイルダンパーは不感帯機構を付属してい ないオイルダンパーと併用している。不感帯機構を用いたモデル(以 下, GAP モデルと称す）のダンパー基数は, 不感帯機構を付属して いないオイルダンパーを 4 基用いたモデルをベースモデルとし, 不 感帯機構付きオイルダンパーを 3 基追加した計 7 基とした。また, 比較対象として不感帯機構を付属していないオイルダンパーを 7 基 使用したモデル（以下，OD モデルと称す）の解析も行う。

\section{2 不感帯機構モデル}

不感帯機構内の挙動を再現するモデルを Fig.6 に示す。自動復帰 ばね, 緩衝ゴムの剛性值, 機構内摩擦など機構内の設定值を詳細に モデル化する。Fig.7 に各部の復元力特性を示す。不感帯機構の緩衝 ゴムの復元力特性を再現するスプリング(2)と不感帯機構全体の剛性 を再現するスプリング(4)の間には解析上はダミー節点を設ける。ス ライダー間を繋ぐ自動復帰ばねはオフセット荷重（ばねが常に圧縮 されている状態）を受けているため, ロッドとスライダーの挙動は 同じとなる。オフセット荷重は $1.47 \mathrm{kN}$ を与え, 不感帯機構剛性（ス プリング (4)）を $4782.19 \mathrm{kN} / \mathrm{mm}$, 不感帯機構とダンパーの総質量（節 点(5)）を $0.680 \mathrm{t}$ とする。スプリング(1)〜 (4)には内部粘性減衰を考慮 しない。また，基本ケースの不感帯幅は $15 \mathrm{~cm}$ とした。おお，自動 復帰ばねや緩衝ゴムの剛性值は設定が自由であるが，この值を変動 させても，建物応答への影響はほとんど無かった。不感帯機構の各 諸元について，設定根拠を付録 A に示す。

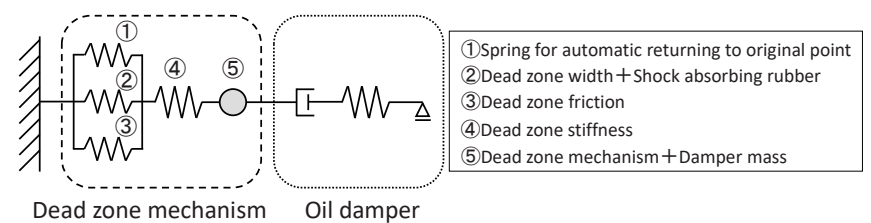

Fig.6 Dead zone mechanism model

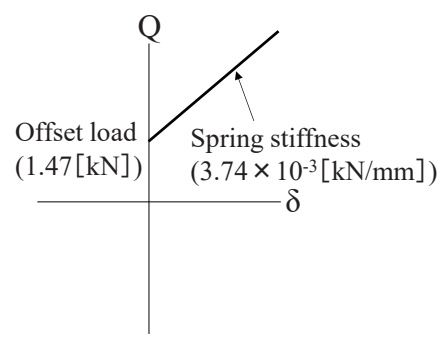

(a) (1) Spring for automatic returning to original position

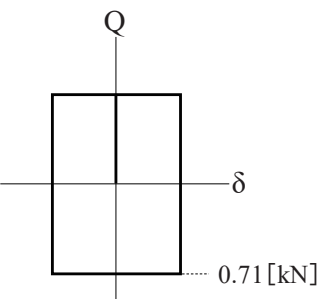

(c) (3)Dead zone friction

Fig.7 Restoring characteristics

\section{3 入力地震動}

入力地震動は，文献 12)に示されている第 2 種地盤相当の代表的 な地盤モデル (地盤-3) で, 逐次非線形解析により増幅させた, Table2 に示す L1〜L3 地震動計 9 波を用いた。ここでの L3 地震動はベース モデルに対して，免震層変位が積層ゴムの変形限界（せん断ひずみ $400 \%$ ）である $62.4 \mathrm{~cm}$ となるよう，L2 地震動の加速度振幅に時刻歴 上で地震動ごとに倍率を乗じたものとした。なお, 免震層固定時の 上部構造の固有周期 $T_{s}$ ごとに倍率は変更する。表中は $T_{s}=1.5 \mathrm{~s}$ のも のである。

また，近年発生が懸念されるパルス性地震動および長周期地震動 を対象とし, 内陸型地震, 海溝型地震を対象とした検討時に使用さ れる傾向にある地震観測記録例えば 13)を, 防災科学技術研究所 K-NET および KiK-net 観測記録 ${ }^{14)}$ ，気象庁 ${ }^{15)}$ より，Table3 および Table4 に 示すそれぞれ 5 地点, 計 10 波ずつを選定した。なお，本報では OD モデルに対する本機構の加速度低減に着目し, 各モデルの応答変位 が L2 地震動想定の変位（15～40 cm 程度）となるケースで応答を比 較するため, パルス性地震動では $\mathrm{PGV}$ を $100 \mathrm{~cm} / \mathrm{s}$, 長周期地震動で は PGV を $50 \mathrm{~cm} / \mathrm{s}$ に基準化して入力地震動とした。Fig. 8 に基準化し た地震動の擬似速度応答スペクトル（減衰 5\%）を示す。スペクト ル值は免震周期 4 秒で $90 \sim 170 \mathrm{~cm} / \mathrm{s}$ となっている。

\section{3. 告示波に対する応答性状}

本章では，不感帯機構を用いた免震建物に対して，L1 L3 地震動 （告示波）を入力地震動として時刻歴応答解析を行い，地震応答性

Table2 Input earthquakes (Publicly announced wave)

\begin{tabular}{|c|c|c|c|c|c|}
\hline \multicolumn{2}{|c|}{ Earthquake } & Name & PGA [cm/s $\left.\mathrm{s}^{2}\right]$ & PGV [cm/s] & Duration time [s] \\
\hline \multirow{3}{*}{ L1(Level 1) } & Hachinohe NS & L1-HA & 108.2 & 17.4 & 234.0 \\
\cline { 2 - 6 } & JMA Kobe NS & L1-KOBE & 114.8 & 14.3 & 359.9 \\
\cline { 2 - 6 } & Random & L1-RD & 78.3 & 14.7 & 81.9 \\
\hline \multirow{3}{*}{ L2 (Level 2) 2) } & Hachinohe NS & L2-HA & 481.8 & 73.6 & 234.0 \\
\cline { 2 - 6 } & JMA Kobe NS & L2-KOBE & 458.7 & 76.3 & 359.9 \\
\cline { 2 - 6 } & Random & L2-RD & 348.8 & 77.3 & 163.8 \\
\hline \multirow{3}{*}{ L3 (Level 3) } & Hachinohe NS & L3-HA & 1060.0 & 161.9 & 234.0 \\
\cline { 2 - 6 } & JMA Kobe NS & L3-KOBE & 890.8 & 148.2 & 359.9 \\
\cline { 2 - 6 } & Random & L3-RD & 727.2 & 161.1 & 163.8 \\
\hline
\end{tabular}

Table3 Input earthquakes (Pulse-like ground motions)

\begin{tabular}{|c|c|c|c|c|c|}
\hline Earthquake & Data type & $\begin{array}{c}\text { Observation } \\
\text { point name }\end{array}$ & Direction & $\begin{array}{c}\text { PGA }\left[\mathrm{cm} / \mathrm{s}^{2}\right] \\
(\mathrm{PGV} 100 \mathrm{~cm} / \mathrm{s})\end{array}$ & $\begin{array}{l}\text { Duration } \\
\text { time [s] }\end{array}$ \\
\hline \multirow{2}{*}{$\begin{array}{l}\text { The South Hyogo prefecture } \\
\text { Earthquake in } 1995\end{array}$} & \multirow{2}{*}{ JMA } & \multirow{2}{*}{ Kobe } & $\mathrm{NS}$ & 901.8 & \multirow{2}{*}{359.9} \\
\hline & & & $E W$ & 815.4 & \\
\hline \multirow{2}{*}{$\begin{array}{c}\text { The Western Tottori prefecture } \\
\text { Earthquake in } 2000\end{array}$} & \multirow{2}{*}{ KiK-net } & \multirow{2}{*}{$\begin{array}{c}\text { Hino } \\
(\text { TTRH02) }\end{array}$} & NS & 739.4 & \multirow{2}{*}{300.0} \\
\hline & & & EW & 872.6 & \\
\hline \multirow{2}{*}{$\begin{array}{l}\text { The Mid Niigata prefecture } \\
\text { Earthquake in } 2004\end{array}$} & \multirow{2}{*}{ K-NET } & \multirow{2}{*}{$\begin{array}{c}\text { Ojiya } \\
\text { (NIG019) }\end{array}$} & NS & & \multirow{2}{*}{299.0} \\
\hline & & & $E W$ & 1017.8 & \\
\hline \multirow{2}{*}{$\begin{array}{l}\text { The Noto Hanto Earthquake } \\
\text { in } 2007\end{array}$} & \multirow{2}{*}{ JMA } & \multirow{2}{*}{ Wajima } & NS & \begin{tabular}{|l|l|}
495.8 \\
\end{tabular} & \multirow{2}{*}{120.0} \\
\hline & & & $E W$ & 531.2 & \\
\hline \multirow{2}{*}{ The 2016 Kumamoto Earthquake } & \multirow{2}{*}{ KiK-net } & \multirow{2}{*}{$\begin{array}{l}\text { Mashiki } \\
(\text { KMMH16) }\end{array}$} & $\mathrm{NS}$ & 756.6 & \multirow{2}{*}{300.0} \\
\hline & & & $E W$ & 896.2 & \\
\hline
\end{tabular}

Table4 Input earthquakes (Long period ground motions)

\begin{tabular}{|c|c|c|c|c|c|}
\hline Earthquake & Data type & $\begin{array}{l}\text { Observation } \\
\text { point name }\end{array}$ & Direction & $\begin{array}{l}P G A\left[\mathrm{~cm} / \mathrm{s}^{2}\right] \\
(P G V 50 \mathrm{~cm} / \mathrm{s})\end{array}$ & $\begin{array}{l}\text { Duration } \\
\text { time [s] }\end{array}$ \\
\hline \multirow{3}{*}{$\begin{array}{l}\text { The Tokachi-oki Earthquake } \\
\text { in } 2003\end{array}$} & \multirow{2}{*}{ K-NET } & \multirow{2}{*}{$\begin{array}{l}\text { Tomakomai } \\
\text { (HKD129) }\end{array}$} & NS & 141.2 & \multirow{2}{*}{290.0} \\
\hline & & & EW & 104.1 & \\
\hline & K-NET & $\begin{array}{l}\text { Ishikari } \\
\text { (HKD178) }\end{array}$ & NS & 124.7 & 233.0 \\
\hline \multirow{2}{*}{$\begin{array}{c}\text { The Mid Niigata prefecture } \\
\text { Earthquake in } 2004\end{array}$} & \multirow{2}{*}{ K-NET } & \multirow{2}{*}{$\begin{array}{l}\text { Shinjuku } \\
\text { (TKY007) }\end{array}$} & NS & 266.1 & \multirow{2}{*}{150.0} \\
\hline & & & $E W$ & 139.1 & \\
\hline \multirow{3}{*}{$\begin{array}{c}\text { The } 2011 \text { off the Pacific coast of } \\
\text { Tohoku Earthquake }\end{array}$} & \multirow{2}{*}{$\mathrm{K}-\mathrm{NET}$} & \multirow{2}{*}{$\begin{array}{l}\text { Akita } \\
\text { (AKT010) }\end{array}$} & NS & 173.9 & \multirow{2}{*}{300.0} \\
\hline & & & EW & 166.1 & \\
\hline & KiK-net & $\begin{array}{l}\text { Shimousa } \\
\text { (CHBH } 04)\end{array}$ & NS & $\frac{579.0}{529.9}$ & 300.0 \\
\hline
\end{tabular}




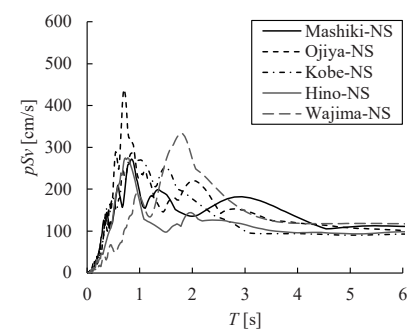

(a) Pulse-like ground motions

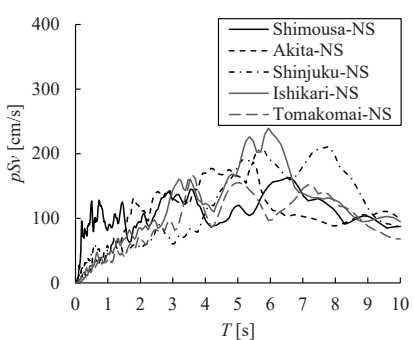

(b) Long period ground motions

Fig. 8 Pseudo velocity response spectrum

状について把握する。また, 不感帯機構内の不感帯幅の設定值や上 部構造の固有周期を変化させた場合の建物の応答性状について把握 する。

\section{1 不感帯幅の設定}

不感帯機構内の不感帯幅の設定をパラメータとし, 5, 10, 15, 20, $25 \mathrm{~cm}$ の 5 ケースで解析を行う。

L1 L3 地震動（RD）の免震層変位最大值と上階絶対加速度最大 值の関係を Fig.9 に示す。不感帯幅が小さい $5 \mathrm{~cm}$ では, L3 時の変位 は小さくなるが L2 時の加速度低減効果は少ない。不感帯幅が大き い $25 \mathrm{~cm}$ では, L2 時の加速度低減効果は高いが, L3 時の変位が大き くなった。また, Fig.10に示すベースモデルに対する GAP モデルの 変位応答倍率と, $\mathrm{OD}$ モデルに対する GAP モデルの加速度応答倍率 の関係より, 不感帯幅 $15 \mathrm{~cm}$ では, L2 時の加速度低減効果と L3 時 の変位抑制効果の両方を平均的に得ることができた。今回の解析ケ ースでは, $15 \mathrm{~cm}$ が効果的であったため, 以降の解析では, 不感帯幅 は $15 \mathrm{~cm}$ とする。なお, 入力地震動のレベルや耐震性能目標值等の 条件によって, この不感帯幅の適正值は変動するため, 設計の際は パラメトリックスタディ等による検討を要する。また, 入力地震動 のレベルが大きい場合, 不感帯幅を小さくすることで L3 地震時の 応答変位を抑制することも可能であるが, L1, L2 地震時の絶対加速 度は増加する。不感帯機構付きオイルダンパーの基数を増やすこと で, L1, L2 地震時の絶対加速度増加も抑制することが可能である。

\section{2 上部構造の固有周期の影響}

免震層固定時の上部構造の固有周期 $T_{s}$ をパラメータとし, $T_{s}=0.5$, $1.0 ， 1.5 ， 2.0 \mathrm{~s}$ の 4 ケースで解析を行う。オイルダンパーの基数は, 4 基（OD4）をベースモデルとし，L3 地震動入力時に免震層変位が クリアランス $60 \mathrm{~cm}$ に収まるよう, 不感帯機構付きオイルダンパー を 2 基（GAP2），または 3 基（GAP3）追加した。

Fig.11 に免震層変位最大值と上階絶対加速度最大值の関係 (RD) を示す。 $T_{s}=0.5,1.0$ では, L2 時の加速度低減効果はあまり確認でき なかったが, 絶対加速度は最大でも $100 \sim 200 \mathrm{~cm} / \mathrm{s}^{2}$ 程度と小さい值 であった。また， $T_{s}=1.5,2.0$ では，L2 時の絶対加速度は最大で 200 $\sim 300 \mathrm{~cm} / \mathrm{s}^{2}$ であり, 平均で $17 \%$ の加速度低減効果が確認できた。上 部構造の固有周期 $T_{s}$ が長い方が不感帯機構の加速度低減効果が表 れやすいと考えられる。

また, Fig.12 に示す $T_{s}=1.5 \mathrm{~s}$ の高さ方向における絶対加速度の最大 值分布より，L2-KOBE ではオイルダンパー基数が 7 基（OD7）の $\mathrm{OD}$ モデルと比較し, GAP モデルで免震層直上および $\mathrm{R}$ 階の絶対加 速度が低減しており, Fig.13 の不感帯機構付きオイルダンパーの履 歴曲線からも不感帯機構の正常な性能発揮が確認できる。しかし,

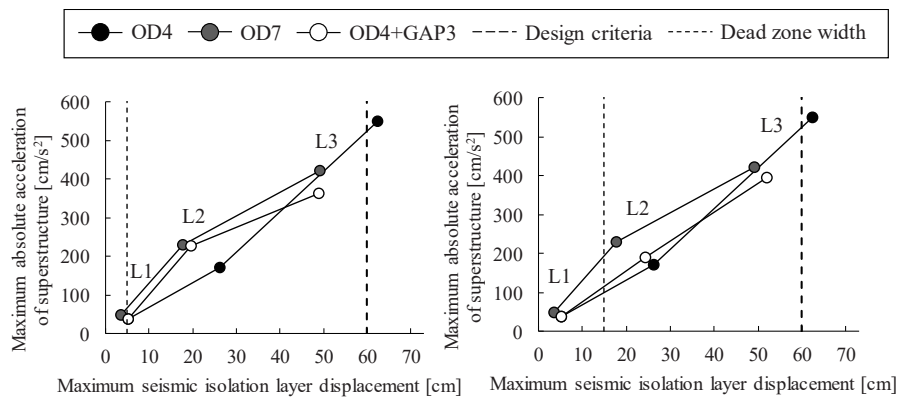

(a) Dead zone width $5 \mathrm{~cm}$

(b) Dead zone width $15 \mathrm{~cm}$

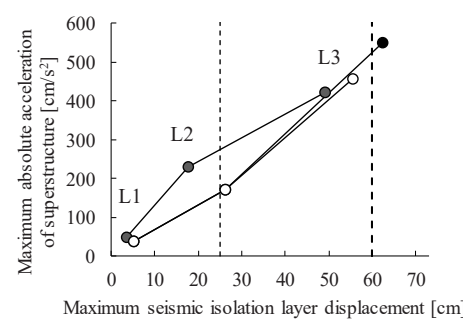

(c) Dead zone width $25 \mathrm{~cm}$

Fig.9 Relation of Acceleration of superstructure and seismic isolation layer displacement (RD)

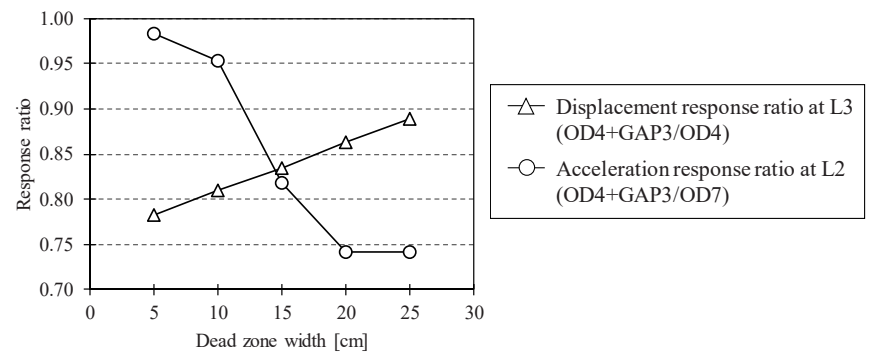

Fig.10 Acceleration and displacement response ratio (RD)

L2-RD では, Fig.13 より不感帯機構は作動しているものの, 最大絶 対加速度は $200 \mathrm{~cm} / \mathrm{s}^{2}$ 以下と小さい值であるが, GAP モデルの下層で 加速度低減効果が見られなかった。なお，今回の解析ではエネルギ 一吸収量を比較すると, 不感帯機構付きオイルダンパーは, 不感帯 機構を付属していないオイルダンパーに対して, L2-KOBE で $21 \%$, L2-RD で 4\%程度であった。また, 不感帯機構付きオイルダンパー の最大応答速度は, L2-KOBE では $52.5 \mathrm{~cm} / \mathrm{s}, \mathrm{L} 2-\mathrm{RD}$ では $25.8 \mathrm{~cm} / \mathrm{s}$ であった。

Fig.14 に免震層直上およびスプリング(4)の時刻歴波形を示す。ス プリング(4)は不感帯機構の剛性を再現するばねであり，不感帯機構 が作動するタイミングを確認できる。スプリング1)（自動復帰のた めのばね）やスプリング(3)（不感帯機構摩擦部）など，その他の履 歴特性でも確認寸ることができるが，ここでは，ば祇剛性が大きく オイルダンパーーの影響を確認し易い, スプリング(4)の履歴を示す。 Fig.14 より免震層变位が不感帯幅に達した際に絶対加速度の増加が 見られ，原因として不感帯機構内の要素同士接触時に発生する反力 が考えられる。なお，GAP モデルの加速度増加が顕著に見られる時 刻の直前では, 免震層直上の応答速度にも増加が見られ, 応答速度 の大きさが加速度増加量に少なからず影響しているものと考えられ る。 

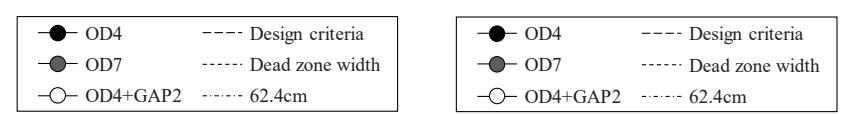

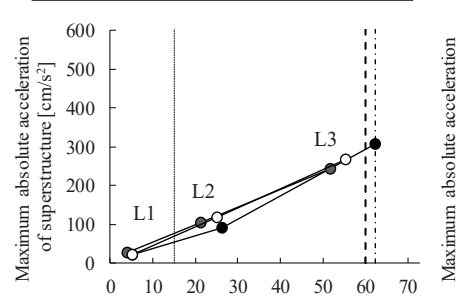

Maximum seismic isolation displacement $[\mathrm{cm}]$

(a) $T_{s}=0.5 \mathrm{~s}$
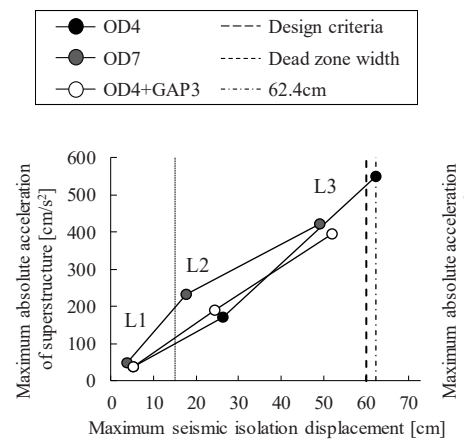

(c) $T_{\mathrm{s}}=1.5 \mathrm{~s}$

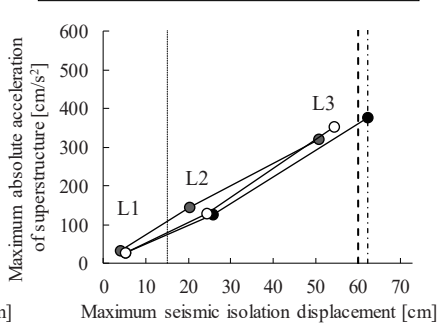

(b) $T_{s}=1.0 \mathrm{~s}$

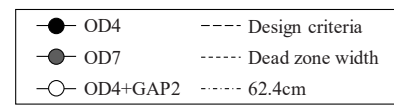

Fig. 11 Relation of acceleration of superstructure and seismic isolation layer displacement (RD)

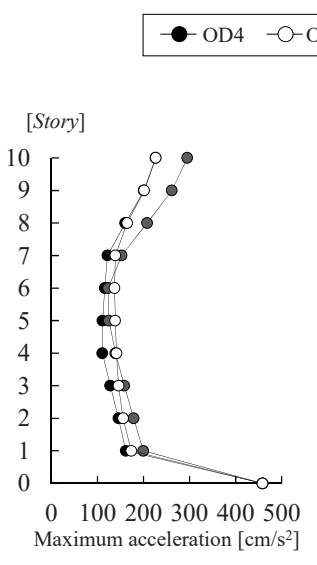

(a) L2-KOBE

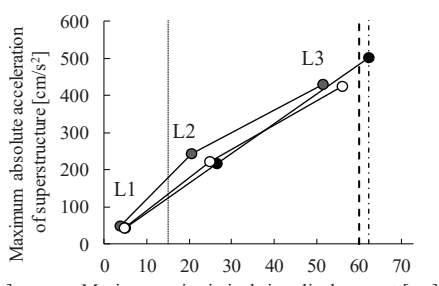

(d) $T_{s}=2.0 \mathrm{~s}$
Fig.12 Maximum response of acceleration

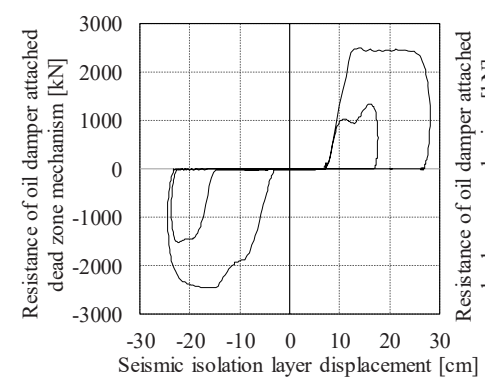

(a) L2-KOBE

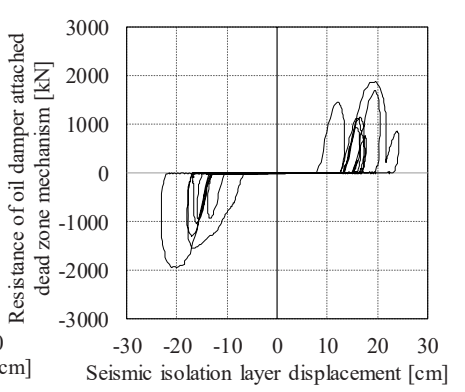

(b) L2-RD
Fig.13 Hysteresis curve of oil damper attached dead zone mechanism

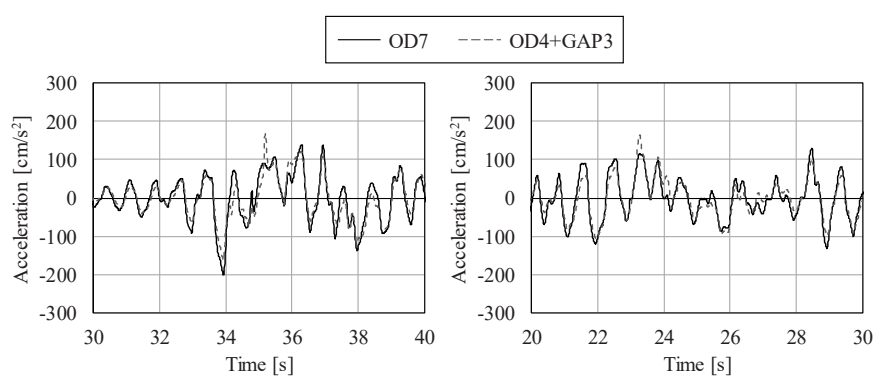

(a) Acceleration of story above seismic isolation
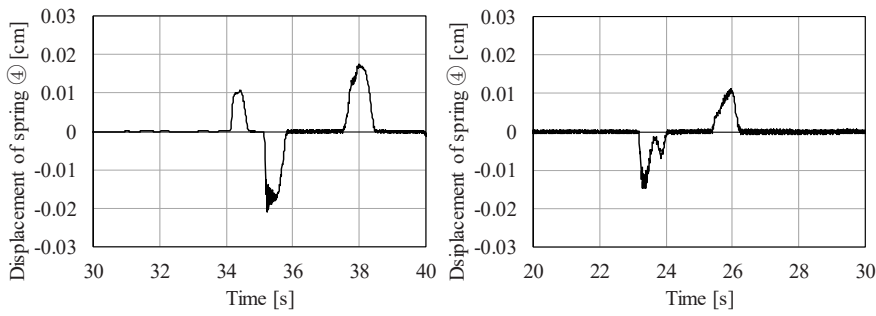

(b) Displacement of spring (4)
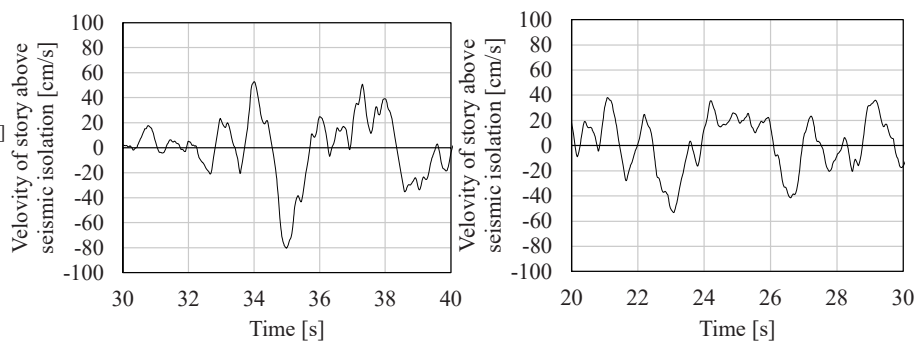

(c) Velocity of story above seismic isolation

Fig.14 Time history wave [Left : L2-KOBE, Right : L2-RD]

\section{3 原点自動復帰}

不感帯機構の特徴の一つとして, 地震終了時（無負荷時）にロッ ドを原点位置まで自動復帰させるスプリング（自動復帰ばね）を搭 載していることが挙げられる。この自動復帰ばねを搭載しない場合, 地震により免震層に変位が生じた後, 残留変位分ロッドが原点位置 に戻らない。この状態で次の地震が発生すると, ロッドが原点位置 にある場合と比較して建物応答が大きくなる可能性がある。そこで, 自動復帰ばねが想定した通りに作動しているか確認を行う。また, 一般的な免震層の維持管理上の残留変位である $5 \mathrm{~cm}$ を超える変形量 として, $\pm 10 \mathrm{~cm}$ の残留変形がある状態から, 告示波を入力した場合 の建物応答について確認する。なお, 残留変形の土 $10 \mathrm{~cm}$ は, スプリ ング(2), (3)の各折れ点の変位を加減することで与えた。

Fig.15 に L2-RD，L3-RD を入力地震動とした場合における節点(5) の変位の時刻歴波形を示す。節点(5)は不感帯機構とダンパーの総質 量を設定した節点である。なお, 残留変形を確認するため, L2-RD, L3-RDの継続時間を 163.8 秒から 200 秒まで延長した。地震終了後 の残留変形は，L2-RD で $0.46 \mathrm{~cm}, \mathrm{~L} 3-\mathrm{RD}$ で $0.85 \mathrm{~cm}$ であり, 概ね原 点位置に自動復帰しており, 自動復帰ばねは想定通りの挙動をして いることが確認できる。一方, 自動復帰ばねが無い場合の残留変形 は，L2-RD で $1.04 \mathrm{~cm}$, L3-RD で $1.71 \mathrm{~cm}$ であり, 自動復帰ばねが原 点方向へ復元している効果を確認した。なお，若干であるが残留変 形が生じる原因は，不感帯機構内の摩擦力と考えられる。

Fig.16に L1 L3 地震動の免震層変位最大值と上階絶対加速度最 
大值の関係を示す。Fig.16(a)は, 解析開始時に残留変形が正側に $10 \mathrm{~cm}$ あるケースの HA 入力時の解析結果, Fig.16(b)は, 解析開始 時に残留変形が負側に $10 \mathrm{~cm}$ あるケースの $\mathrm{KOBE}$ 入力時の解析結果 である。Fig.16(a)より L2-HA では, ロッドが原点位置から始動す る場合と比較して, 残留変形がある状態から始動したモデルの加速 度応答は, 約 15\%低減していた。また, Fig.16(b)より L2-KOBEで は, 加速度応答は約 $14 \%$ 増加していた。地震動によっては応答が低 減するケースがあるが，反対に応答が増加するケースもあることを 確認した。したがって, 残留変形があると加速度応答に影響を及ぼ すため, 不感帯機構内の自動復帰ばねがロッドを原点位置に自動復 帰させることが重要であり, 短期間に複数回地震が起きた場合にも 設計時に想定した, Fig.1に示した目標性能を保持することが可能で あると考えられる。

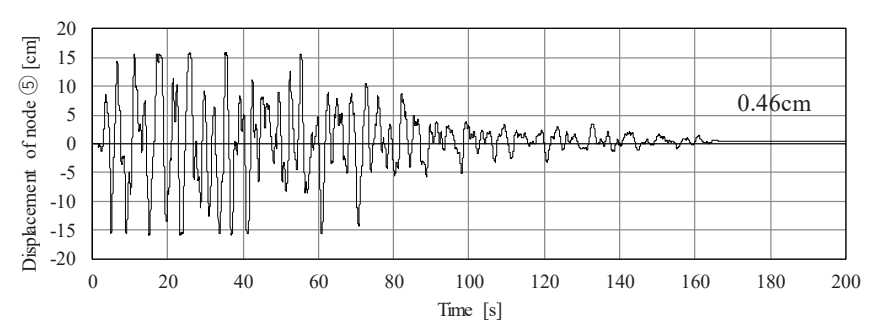

(a) L2-RD

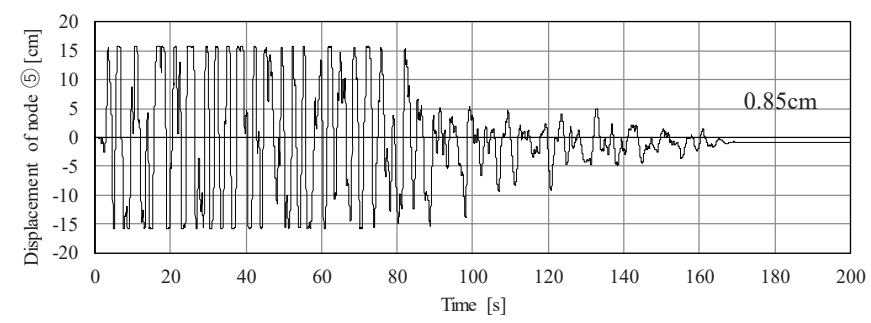

(b) L3-RD

Fig.15 Displacement of node (5)

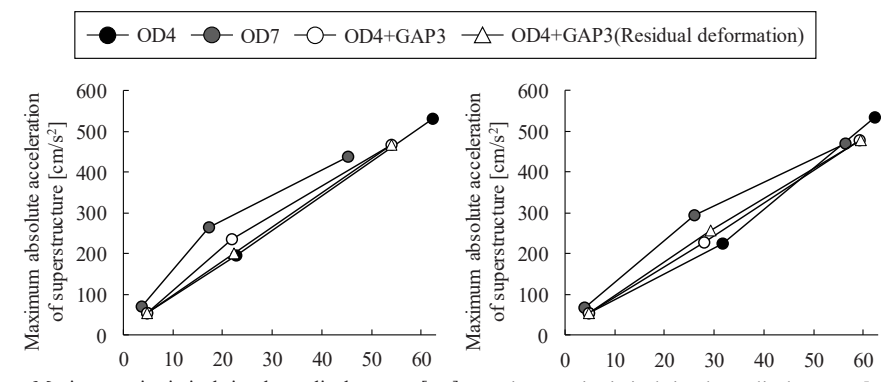

Maximum seismic isolation layer displacement $[\mathrm{cm}]$ Maximum seismic isolation layer displacement $[\mathrm{cm}]$

(a) HA (Residual

(b) KOBE (Residual

deformation $+10 \mathrm{~cm}$ )

deformation $-10 \mathrm{~cm}$ )

Fig.16 Relation of acceleration of superstructure and seismic isolation layer displacement

\section{4. 観測地震動に対する応答性状}

本章では，不感帯機構を用いた免震建物に対して，近年発生が懸 念されるパルス性地震動および長周期地震動を入力地震動として時 刻歴応答解析を行い，地震応答性状について把握する。

各地震動について横軸に免震層変位, 縦軸に上階の絶対加速度の
各最大值をプロットしたものを Fig.17 に示す。また，神戸 NS，益 城 $\mathrm{EW}$, 石狩 $\mathrm{EW}$, 新宿 $\mathrm{EW}$ の解析結果における GAP モデルと $\mathrm{OD}$ モデルの各階の最大絶対加速度の比較を Fig.18 および Fig.19 に, 免 震層直上階の時刻歴波形, GAP モデルにおける不感帯機構の剛性を 再現するばね（スプリング(4)）の時刻歴波形を Fig.20 および Fig.21 に示す。

パルス性地震動では Fig17 より, OD モデルに対し GAP モデルの 加速度低減効果が高く, 平均で約 $20 \%$ の加速度低減が確認できる。 また, Fig.18より, 神戸 NS, 益城 EW では OD モデルと比較し GAP モデルで免震層直上および $\mathrm{R}$ 階の絶対加速度が低減していることが わかる。

長周期地震動では Fig.19 および Fig.21より, 各地震動の絶対加速 度は $100 \sim 200 \mathrm{~cm} / \mathrm{s}^{2}$ 程度と免震建物として許容できる範囲の応答で あるが，GAP モデルの各階で加速度低減効果が見られなかった。 Fig.20 および Fig.21 の免震層直上階の時刻歴波形から，いずれの地 震動に対しても免震層変位が不感帯幅に達した際に，機構内の要素 同士接触時の影響が，上階全体の応答に対する割合として大きくな ったことで, GAP モデルの加速度応答の増加が顕著に表れたと考え られる。なお, パルス性地震動時にも機構内の要素同士接触が発生 しているが, 長周期地震動と比較して, 入力加速度が大きいため上 階全体の応答が大きく,その影響が割合として小さいと考えられる。

\section{\begin{tabular}{llll}
$\circ$ & OD7 & OD4 $+\mathrm{GAP} 3$ \\
\hline
\end{tabular}}
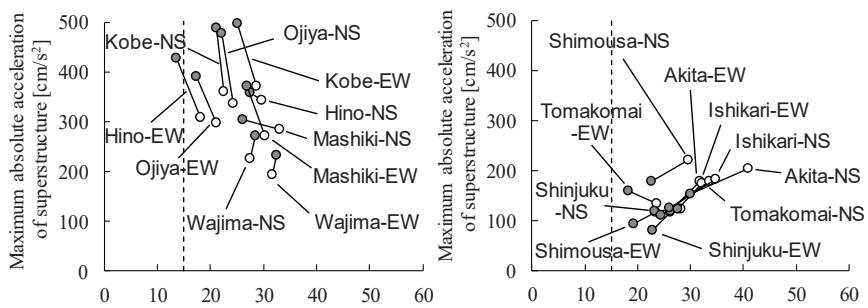

Maximum seismic isolation layer displacement $[\mathrm{cm}]$ Maximum seismic isolation layer displacement $[\mathrm{cm}]$

(a) Pulse-like ground motions

(b) Long period ground motions Fig.17 Relation of acceleration and displacement of seismic isolation layer

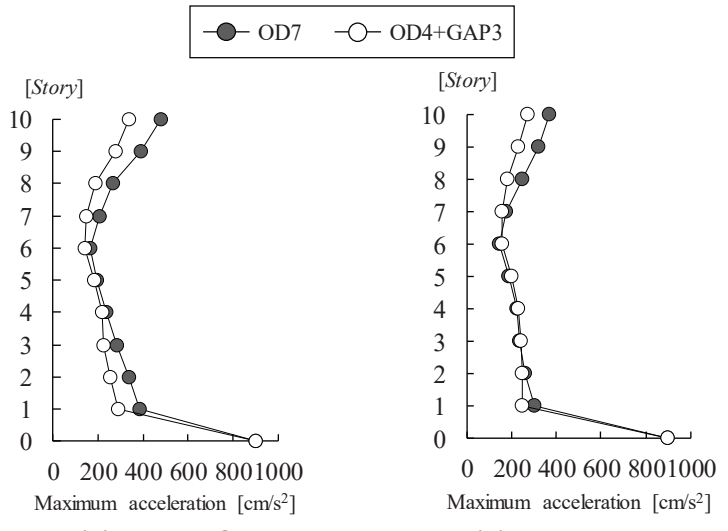

(a) Kobe-NS

(b) Mashiki-EW

Fig.18 Maximum response of acceleration [Pulse-like ground motions] 


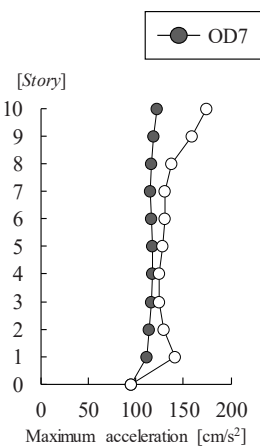

(a) Ishikari-EW

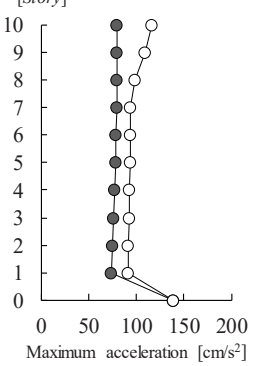

(b) Shinjuku-EW
Fig.19 Maximum response of acceleration [Long period ground motions]
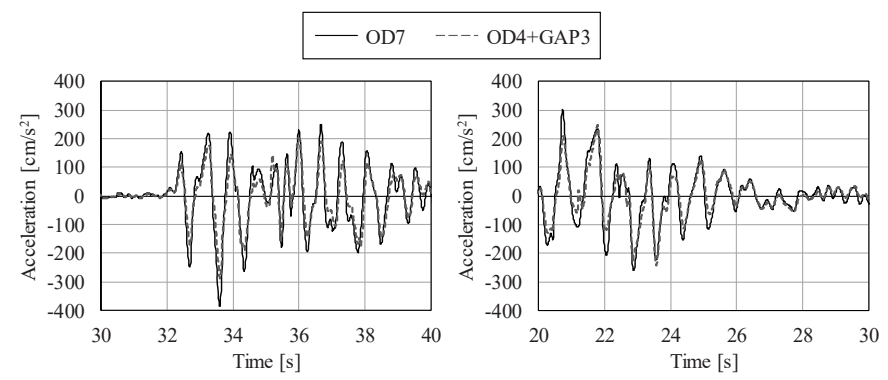

(a) Acceleration of story above seismic isolation layer
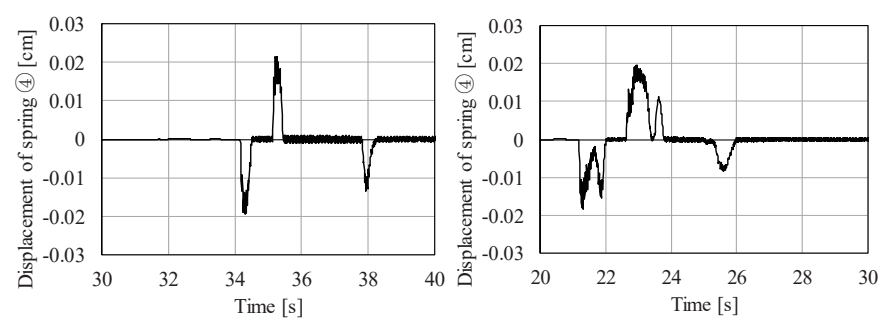

(b) Displacement of spring (4)

Fig.20 Time history wave of pulse-like ground motions [Left : Kobe-NS, Right : Mashiki-EW]
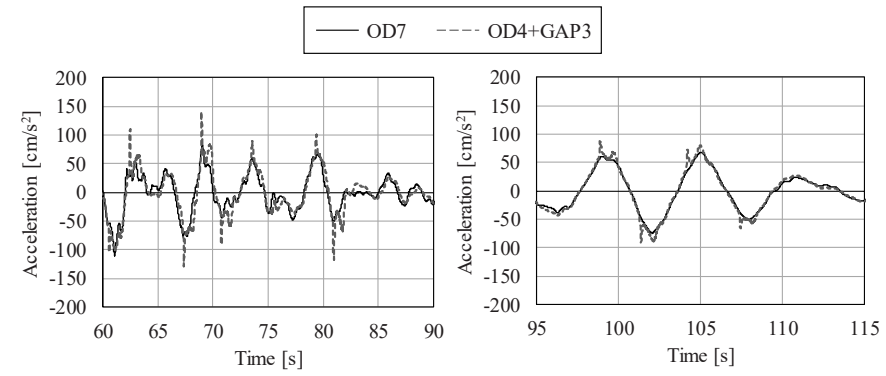

(a) Acceleration of story above seismic isolation layer
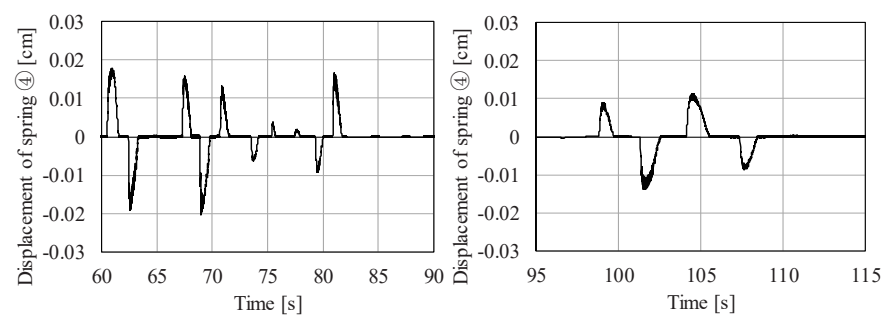

(b) Displacement of spring (4)

Fig.21 Time history wave of long period ground motions [Left : Ishikari-EW, Right : Shinjuku-EW]

\section{5. 居住性能評価}

不感帯機構付きオイルダンパーは, L1，L2 地震時の加速度応答を 低減することが目的であるが，機構内要素同士の接触が原因と考え られるパルス的な加速度が問題とならないことを確認するため, 本 章では告示波および観測波を入力地震動とした地震応答解析の結果 に $1 / 3$ オクターブバンド分析を適用し，居住性能に及ぼす影響を把 握する。

\section{1 告示波に対する居住性能評価}

L2 の告示波を入力した場合の加速度応答の時刻歴波形に対し， 1/3 オクターブバンド分析を適用して Fig.22 に示す。加速度応答は 免震層直上階の応答とする。L2-KOBE を入力とした場合には短周期 帯では，OD モデルの OD7 が最も大きく，長周期帯ではベースモデ ルの OD4 が大きくなることが確認でき，GAP モデルの OD4+GAP3 は平均的な応答を示していることがわかる。L2-RD の場合には OD4+GAP3 が最も大きくなる周期帯もあるが, 突出した増加は確認 されない。今回検討を行った振幅範囲が対応可能な高橋らの研究に よる不安度評価における評価曲線 ${ }^{16)}$ では, 最も不安度が低いランク の判定值は $0.6 \sim 1.0$ 秒付近で $0.4 \mathrm{~m} / \mathrm{s}$ 程度, $3 \sim 6$ 秒では $0.5 \sim 1.0 \mathrm{~m} / \mathrm{s}$ と示されており，全ケースにおいて応答は判定值より十分に小さい 值となっている。よって, 機構内の要素接触時の加速度応答の増加 が居住性能に及ぼす影響は小さいと考えられる。

\section{2 観測波に対する居住性能評価}

パルス性地震動と長周期地震動を対象とした，不感帯機構付き才 イルダンパーを有する免震建物の絶対加速度の時刻歴波形に対して, 1/3 オクターブバンド分析を適用して Fig.23 に示寸。パルス性地震 動の例として益城 EW の結果を Fig.23(a)に, 長周期地震動の例とし て石狩 EW の結果を Fig.23(b)に示す。Fig.23(a)より益城 EW を入力 とした場合には短周期帯の応答が大きくなり長周期帯の応答が抑え られる。一方, Fig.23(b)より石狩 EW を入力とした場合には長周期 帯の応答が大きくなる。しかし，いずれの場合でも不感帯機構を用 いた際の突出した応答の増加は確認されず，告示波と同様に高橋ら の評価曲線と比較すると, 全周期帯において不安度が最も低いラン クの判定值より十分小さい值となっており，機構内の要素接触時の 加速度応答の増加が居住性能に与える影響は小さいと考えられる。

\section{- OD4 -O- OD7 -O- OD4+GAP3}

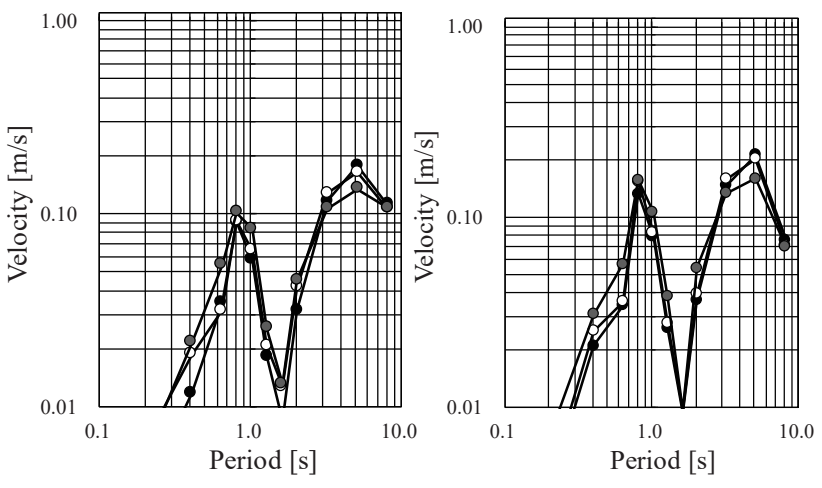

(a) L2-KOBE

(b) L2-RD

Fig.22 Results of $1 / 3$ octave band analysis (Publicly announced wave) 


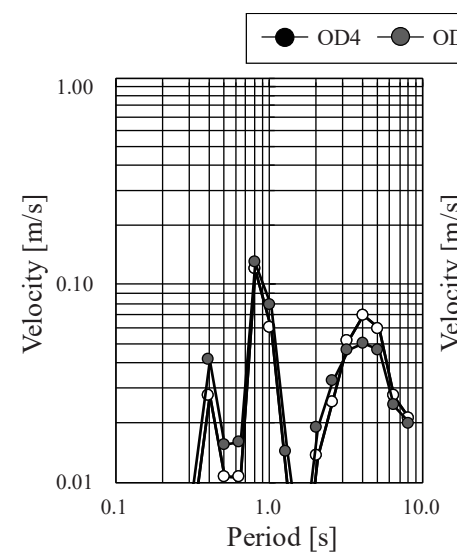

(a) Mashiki-EW

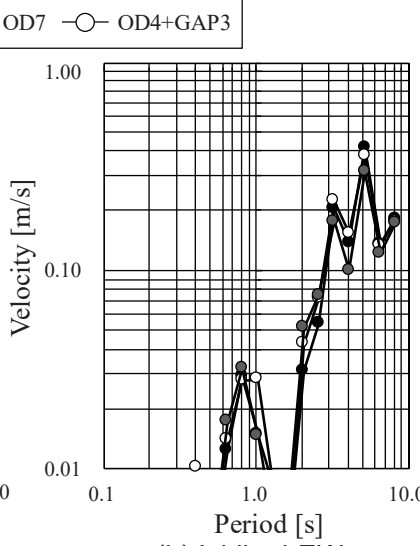

(b) Ishikari-EW
Fig. 23 Results of $1 / 3$ octave band analysis (Observed earthquake wave)

\section{6. まとめ}

本報では，不感帯機構付きオイルダンパーを用いた免震建物に対 して, 告示波および観測地震動を入力地震動として地震応答解析を 行い, 応答性状を把握した。また, 地震応答解析結果に $1 / 3$ オク夕 ーブバンド分析を適用し, 不感帯機構が建物の居住性能に及ぼす影 響について把握した。以下に結論をまとめる。

i）告示波およびパルス性地震動を入力地震動とした場合, 不感帯 機構付きオイルダンパーを免震建物に用いることで, 中小地震 動に対する免震性能を確保しつつ，大振幅地震動に対する免震 層の過大変位を抑制する効果が得られることを確認した。また, 今回の解析ケースでは, 不感帯幅が $15 \mathrm{~cm}$ の時に, L2 時の加速 度低減効果と L3 時の変位抑制効果の両方を平均的に得ること ができた。

ii）不感帯機構内の自動復帰ばねが, 地震終了時にロッドを概ね原 点位置に自動復帰させることを確認した。また, ロッドが原点 位置から始動する場合と比較して, 残留変形がある状態から始 動したモデルの加速度応答は, 最大で約 $15 \%$ の差があることを 確認した。したがって, 不感帯機構内の自動復帰ばねがロッド を原点位置に自動復帰させることで, 短期間に複数回地震が起 きた場合にも, 設計時に想定した構造性能を保持することが可 能であると考えられる。

iii）長周期地震動を入力地震動とした場合, OD モデルに比べ GAP モデルの加速度応答が大きくなったが, 絶対加速度は 100〜 $200 \mathrm{~cm} / \mathrm{s}^{2}$ 程度と小さく, 免震建物として許容できる範囲の応答 となった。

iv）今回検討に用いたいずれの地震動においても, 免震層変位が不 感帯幅に達した際に, 下層で絶対加速度の増加が見られた。原 因として不感帯機構内の要素同士接触時に発生する反力が考え られる。そこで, 各モデルの免震層直上階における絶対加速度 の時刻歴波形に対して $1 / 3$ オクターブバンド分析を適用し, 居 住性能の評価を行った。高橋らの研究による不安度評価におけ る評価曲線と比較し, 最も不安度が低いランクの判定值より十 分小さい值であり, 不感帯機構内の要素同士接触時の加速度応 答の増加が居住性能に及ぼす影響は小さいことを確認した。

なお, 本工法の実用化のため, 今後は実機による性能確認実
験を行う予定である。

\section{謝辞}

防災科学技術研究所 K-NET および KiK-net 観測記録，気象庁の 公開データを使用させていただきました。

\section{参考文献}

1) Nagashima, I., Shinozaki, Y., Maseki, R., Sanui, Y., and Kitagawa, Y.: Sliding Mode Control of Base-Isolation System using Semi-Active Hydraulic Damper, Journal of Structural and Construction Engineering (Transactions of AIJ), Vol. 75 No.649, pp.511-519, 2010.3 長島一郎, 篠崎洋三, 欄木龍大, 讃井洋一, 北川良和 : 可変減衰才イ ルダンパーを用いた免震構造物のスライディングモード制御, 日本建 築学会構造系論文集，第 75 巻，第 649 号，pp.511-519, 2010.3

2) Suzuki, T., Watakabe, M., Yachiune, K., Inai, S., Nitta, Y. and Nishitani, A.: Development if Semi-active Base-isolation System using Variable Damping Device (Part1 Variable Damping Device and Control Law), Summaries of Technical Papers of Annual Meeting, Architectural Institute of Japan, Structures-II, pp.395-396, 2013.7

鈴木太輝雄, 渡壁守正, 谷地畧和夫, 稲井慎介, 仁田佳宏, 西谷章 : 可変減衰セミアクティブ免震構造の開発(その 1 可変減衰オイルダン パーの基本性能と制御則), 日本建築学会大会学術講演梗概集, 構造 II, pp.395-396, 2013.7

3) Maseki, R., Nagashima, I., Arai, A., and Kimura, Y.: Development of Passive Variable oil Damper and Its Application for Short Stroke Seismic Isolated Structure, Journal of Structural Engineering, Vol. 58B, 225-230, 2012.3 欄木龍大, 長島一郎, 新居藍子, 木村雄一 : パッシブ型可変オイルダ ンパーの開発と小ストローク免震構造物への適用性, 構造工学論文集, 第 58B 巻, pp.225-230, 2012.3

4) Nishimura, N., Kishida, A. and Taga, K.: Study on Response Reduction Methods for Base Isolated Buildings with Collision to a Retaining Wall (Part1), Summaries of Technical Papers of Annual Meeting, Architectural Institute of Japan, Structures-II, pp.505-506, 2015.7

西村奈緒, 岸田明子, 多賀謙蔵 : 擁壁との衝突を考慮した免震建物の 応答低減手法に関する研究(その 1), 日本建築学会大会学術講演梗概集, 構造 II , pp. 505-506, 2015.7

5) Hukukita, A., Kitamura, Y., Hama, T., Isoda, K., and Sakakibara, K.: Development of the Oil Damper with Variable Resistance Force Part1 Basic Characteristics of the Oil Damper and Response Analysis, Summaries of Technical Papers of Annual Meeting, Architectural Institute of Japan, Structures-II, pp.991-992, 2017.7

福喜多輝, 北村佳久, 濱智貴, 磯田和彦, 榊原健人 : 可変減衰オイル ダンパーの開発（その1 ダンパーの基本特性と解析的検討）, 日本建 築学会大会学術講演梗概集, 構造 II, pp.991-992, 2017.7

6) Maseki, R., Nagashima, I., Arai, A., Kimura, Y., and Nishitani, A.: Response Control of Seismic Isolated Buildings using Developed Passive-Switching Oil Damper with Bi-Flow Mechanism, Journal of Structural and Construction Engineering (Transactions of AIJ), Vol. 80 No. 713, 1023-1032, 2015.7 欄木龍大, 長島一郎, 新居藍子, 木村雄一, 西谷章 : バイフロー式パ ッシブ可変オイルダンパーの開発とそれを用いた免震構造物の応答制 御, 日本建築学会構造系論文集, 第 80 巻, 第 713 号, pp.1023-1032, 2015.7

7) Fukumi, Y., Watanabe, T., Emura, M., Yamanaka, M., Katsumata, H., and Ota, H.: Development of New style variable oil damper Part.1 System of the damper, Summaries of Technical Papers of Annual Meeting, Architectural Institute of Japan, Structures-II, pp.405-406, 2016.7

福見祐司, 渡辺哲巳, 江村勝, 山中昌之, 勝俣英雄, 太田博之 : 減衰 性能可変型オイルダンパーの開発（その 1 ダンパー機構），日本建築 学会大会学術講演梗概集, 構造 II, pp.405-406, 2016.7

8) Tokuno, M., Ohta, Y., Inai, S., Tsuyuki, Y., Ando, T., Misu, M., Kato, N. and Shirai, H.: Development of Dead Zone System Connected to Oil Damper for Seismically Isolation Structure (Part1 Summary of the Dead Zone System and Seismic Response Analysis), Summaries of Technical Papers of Annual Meeting, Architectural Institute of Japan, Structures-II, pp.403-404, 2016.7 得能将紀, 太田行孝, 稲井慎介, 露木保男, 安藤智紀, 三須基規, 加 
藤直樹, 白井宏和 : 免震用オイルダンパーに接続する不感帯機構の開 発(その 1 不感帯機構の概要と地震応答解析), 日本建築学会大会学術 講演講演梗概集，構造 II , pp.403-404, 2016.7

9) Suzuki, A., Kobayashi, M., Yachiune, K., and Tokunou, M.: Seismic Response Characteristic of Base Isolation Structure Using GAP System Connected to Oil Damper, Summaries of Technical Papers of Annual Meeting, Architectural Institute of Japan, Structures-II, pp.835-836, 2018.7

鈴木彰, 小林正人, 谷地畧和夫, 得能将紀 : GAP 機構付きオイルダンパ 一を用いた免震建物の地震応答性状, 日本建築学会大会学術講演梗概集, 構造 II , pp.835-836, 2018.7

10) Suzuki, A., Kobayashi, M., Yachiune, K., and Tokunou, M.: Seismic Response Characteristic of Base Isolation Structure Using GAP System Connected to Oil Damper, Summaries of Technical Papers of Annual Meeting, Architectural Institute of Japan, Structures-II, pp.247-248, 2019.7

鈴木彰, 小林正人, 谷地畧和夫, 得能将紀 : GAP 機構付きオイルダンパ 一を用いた免震建物の地震応答性状（その 2 パルス性地震動および長 周期地震動に対する応答性状), 日本建築学会大会学術講演梗概集, 構 造 II , pp.247-248, 2019.7

11) Architectural Institute of Japan: Recommendation for the Design of Seismically Isolated Buildings, p.276, 2013.10

日本建築学会 : 免震構造設計指針, p.276, 2013.10

12) Architectural Institute of Japan: Seismic Response Analysis and Design of Buildings Considering Dynamic Soil-Structure Interaction, 2006.2

日本建築学会 : 建物と地盤の動的相互作用を考慮した応答解析と耐震設 計, 2006.2

13) Kinoshita,T.,Hamaguchi,H.,Minewaki,S.:Fundamental study on limit state of isolated buildings in pulslike seismic ground motions, Summaries of Technical Papers of Annual Meeting, Architectural Institute of Japan, Structures-II, pp.887-888, 2017.7

木下貴博, 濱口広樹, 嶺脇重雄 : パルス性地震動を受ける免震建物の 終局状態に関寸る基礎的検討, 日本建築学会大会学術講演梗概集, 構造 II , pp.887-888, 2017.7

14) National Research Institute for Earth Science and Disaster Resilience(NIED): Kyoushinkansokumou(K-NET.KiK-net),

http://www.kyoshin.bosai.go.jp/kyoshin/, (accessed 2020.7.8)

防災科学技術研究所: 強震観測網 (K-NET. KiK-net), 防災科学技術研究 所ホームページ, (参照 2020.7.8)

15) Ministry of Land, Infrastructure, Transport, and Tourism Japan Meteorological Agency: Omonajishinnokyoushinkansokude-ta (Main data of Strong-motion Records of Earthquakes),

http://www.data.jma.go.jp/svd/eqev/data/kyoshin/jishin/index.html/, (accessed 2020.7.8)

国土交通省 (気象庁) : 主な地震の強震観測データ, 国土交通省（気象 庁）ホームページ，(参照 2020.7.8)

16) Takahashi, T., Suzuki, T., Saito, T., Azuhata, T. and Morita, K.: Shaking Table Test for Indoor Human Response and Evaluation Limit, JOINT CONFERENCE PROCEEDINGS, $7^{\text {th }}$ International Conference on Urban Earthquake Engineering (7CUEE) \& $5^{\text {th }}$ International Conference on Earthquake Engineering (5ICEE), Tokyo Institute of Technology, Tokyo, Japan, pp.187-193, 2010.3

17) Oota, Y., Yasui, M., Koyama, K., Tsuruga, T., Izumi, N.: Damage assessment of 30-story reinforced concrete frame using long-period ground motion caused by a huge earthquake along the Nankai Trough, Japan Earthquake Engineering Symposium, pp.1461-1470, 2018.12

太田行孝, 保井美敏, 小山和樹, 釣賀達稀, 和泉信之 : 南海卜ラフ沿 いの巨大地震による長周期地震動を用いた 30 階建鉄筋コンクリート造 骨組の被災度評価, 日本地震工学シンポジウム論文集, pp.1461-1470, 2018.12

\section{付録 A 解析モデルに用いた不感帯機構の諸元}

本工法の不感帯機構各部の部材構成を Fig.A1 に示す。解析に用いた各部の諸 元は, 免震部材として実用化のための試験体設計值を用いた。その設定根拠を 示す。

不感帯機構の体積は, Fig.A1 に示寸(1)〜9)各部の合計が $0.061 \mathrm{~m}^{3}$ であり, 単位体積重量が $77.18 \mathrm{kN} / \mathrm{m}^{3}$ のため, 重量は $4.727 \mathrm{kN}$ である。鋼材同士の一般 的な摩擦係数 0.15 と仮定して, 不感帯機構摩擦力は $0.709 \mathrm{kN}$ となる。既製品
であるオイルダンパーの重量は $2.206 \mathrm{kN}$ より，オイルダンパーの摩擦力は $0.331 \mathrm{kN}$ である。自動復州ばねオフセット荷重は, 不感帯機構摩擦力とダン パー摩擦力の合計 $1.04 \mathrm{kN}$ を上回る $1.47 \mathrm{kN}$ と設定した。自動復帰ばね剛性は, 建物応答への影響がほとんど無いが，低めの剛性值として $3.74 \times 10^{-3} \mathrm{kN} / \mathrm{mm}$ を設定し，オフセット荷重 $1.47 \mathrm{kN}$ となるよう $393 \mathrm{~mm}$ 圧縮して機構内に設置 する設計とした。不感帯機構の軸方向剛性は，各構成部材の剛性（断面積 $\times$ ヤング率 $205940 \mathrm{MPa}$ /部材長) の直列和となるが, Fig.A1 に示す值を用いて算 出すると, $4782186 \mathrm{kN} / \mathrm{m}$ となる。緩衝ゴムは, 金型成形による加硫接着ゴムを 製作可能な形状として, 内径 $\Phi 184 \mathrm{~mm}$, 幅 $6 \mathrm{~mm}$, 厚さ $10 \mathrm{~mm}$ とし, 復元力特 性は, 圧縮軸力載荷の実大実験による結果を近似して用いた。

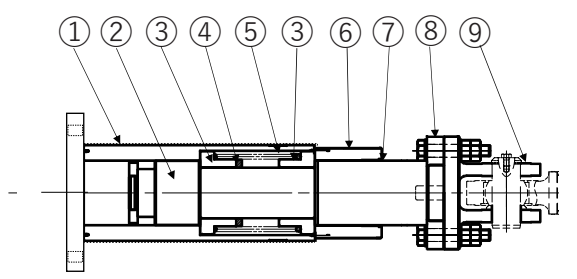

\begin{tabular}{|c|c|c|c|}
\hline Number & Element name & Area $\left(\mathrm{mm}^{2}\right)$ & Length $(\mathrm{mm})$ \\
\hline$(1)$ & Tube & 19946 & 455 \\
\hline$(2)$ & Rod & $31416 \sim 41548$ & $60 \sim 405$ \\
\hline$(3)$ & Slider & $18473 \sim 42798$ & $50 \sim 77$ \\
\hline (4) & Shock absorbing rubber & - & - \\
\hline (5) & Spring & - & - \\
\hline (6) & Head cover & $32103 \sim 253684$ & $50 \sim 135$ \\
\hline$(7)$ & Packing & - & - \\
\hline$(8)$ & Connection plate & - & - \\
\hline (9) & Bracket & - & - \\
\hline
\end{tabular}

Fig.A1 Configuration of dead zone mechanism

\section{付録 B 不感帯機構内緩衝ゴムの最大変形量}

不感帯機構内緩衝ゴムの最大変形量を確認寸る。Fig.A2 に L2 地震動による GAP モデルのオイルダンパー反力時刻歴波形を, Fig.A3 に緩衝ゴム変位の時 刻歴波形を示す。オイルダンパー最大減衰力時の緩衝ゴムの変位は, L2-KOBE で $15.80 \mathrm{~cm}$, L2-RD で $15.74 \mathrm{~cm}$ となっている。Fig.A4 に緩衝ゴムの復元力特 性と最大変形量を示す。最大変形量は解析モデル上の第 3 勾配に位置してい ることがわかる。不感帯幅 $(15 \mathrm{~cm})$ に達した後の変形量はわずかであること がわかる。

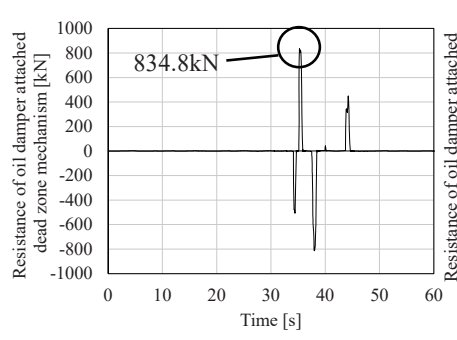

(a) L2-KOBE

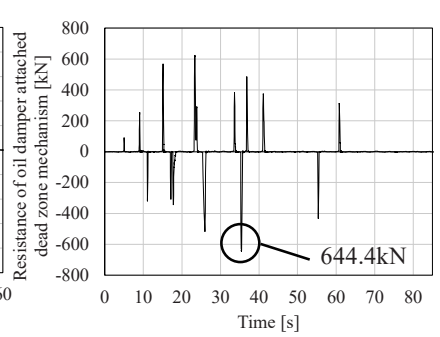

(b) L2-RD
Fig.A2 Resistance of oil damper attached dead zone mechanism

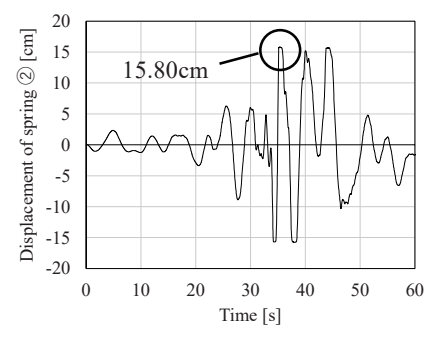

(a) L2-KOBE (b) L2-RD

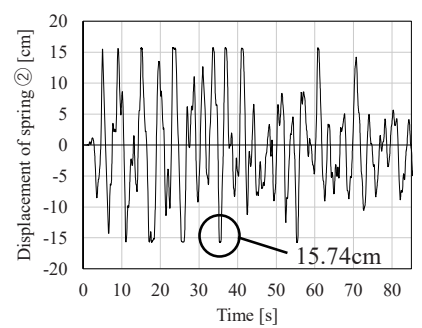

Fig.A3 Displacement of spring(2) 


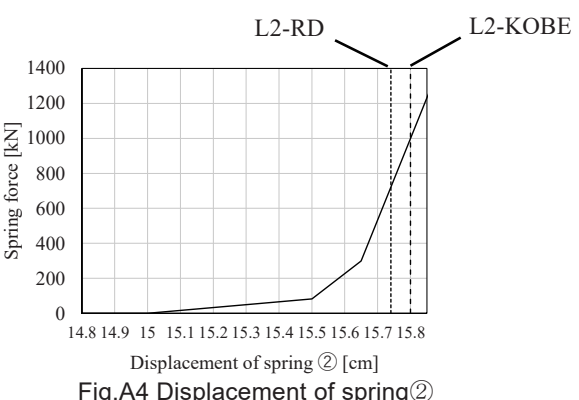

Fig.A4 Displacement of spring(2)

付録 C 機構内要素同士の接触による加速度増加と減衰モデルの検討

本稿の解析条件として, 減衰評価方法を免震層固定時の上部構造の 1 次固有 周期に対して減衰定数 $2 \%$ の剛性比例型減衰としている。不感帯機構内の要素 同士が接触する際の, 加速度増加に対する上部構造の減衰モデルの影響を確認 するため, 1 次固有周期に対する減衰定数を $1 \%$ に低减した解析を行い, 最上 階の床加速度応答スペクトルを比較した。

Fig.A5 に Kobe-NS による各階の最大絶対加速度を，Fig.A6 に Ishikari-EW に よる最大絶対加速度を示す。減衰定数を $1 \%$ に低減したことで, 各モデル各階 全体にわたり, Kobe-NS で 2〜3 割程度, Ishikari-EW で 1 割程度絶対加速度が 大きくなっており, 上部構造の減衰モデルが絶対加速度の最大応答に影響して いることがわかる。Fig.A7 および Fig.A8 には，Kobe-NS，Ishikari-EW による最 上階の絶対加速度応答の時刻歴波形から求めた, 減衰定数 $5 \%$ の床加速度応答 スペクトルを示す。なお, 固有值解析の結果, 固有振動数は 1 次モードが $0.24 \mathrm{~Hz}$ であり, 2 次は $1.22 \mathrm{~Hz}, 3$ 次 $2.34 \mathrm{~Hz}, 4$ 次 $3.41 \mathrm{~Hz}, 5$ 次 $4.39 \mathrm{~Hz}$ であった。 Fig.A7 の Kobe-NS では, 減衰の違いによる 2 次および 3 次モードの加速度応答の差が 大きく, 絶対加速度応答に高次モードが強く影響していることがわかる。一方, Fig.A8 の Ishikari-EW によると, GAP モデルは隇衰の違いによる 2 次および 3 次モードの加速度応答にほとんど差がないが, OD モデルは減衰定数 $1 \%$ の方が 2 割程度大きい。したがって, 地震動によっては, 上部構造の減衰モデルの違 いが機構内要素同士の接触による加速度増加に大きな影響を与える可能性が ある。以上のことから，機構内要素同士の接触による加速度増加の影響を检討 する際には，上部構造の減衰モデルの設定にも留意する必要がある。

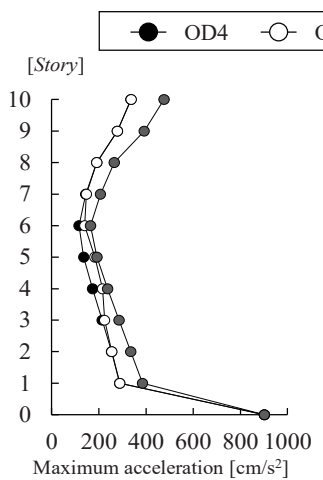

(a) $\mathrm{h}=0.02$

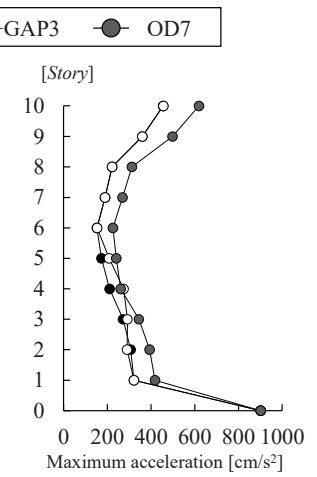

(b) $h=0.01$
Fig.A5 Maximum response of acceleration (Kobe-NS)

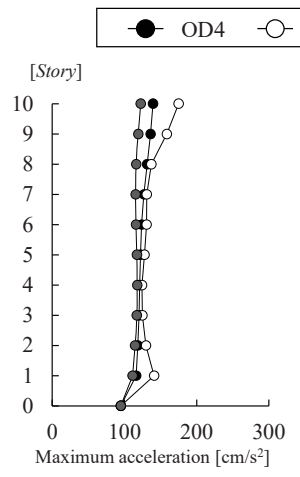

(a) $\mathrm{h}=0.02$

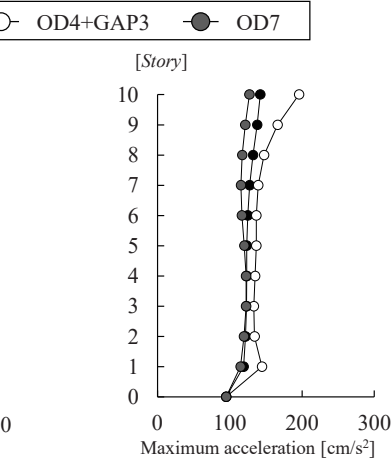

(b) $h=0.01$
Fig.A6 Maximum response of acceleration (Ishikari-EW)

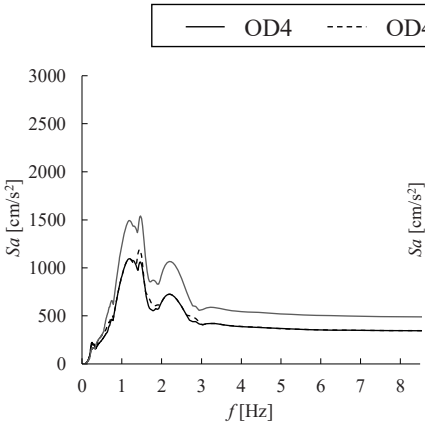

(a) $\mathrm{h}=0.02$

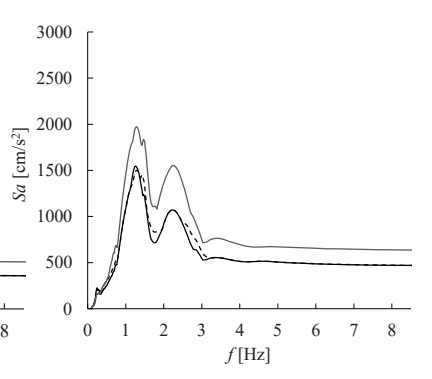

(b) $h=0.01$
Fig.A7 Acceleration response spectrum (Kobe-NS)

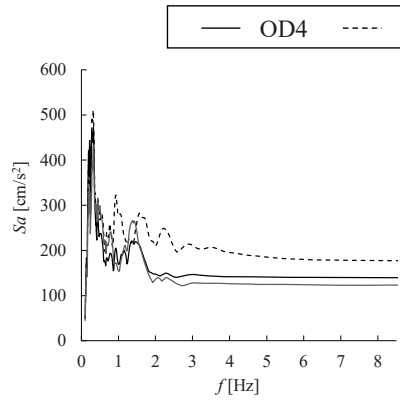

(a) $\mathrm{h}=0.02$

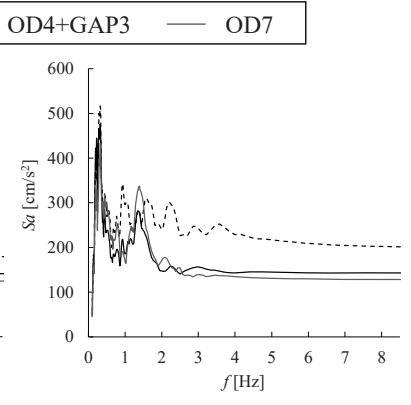

(b) $\mathrm{h}=0.01$
Fig.A8 Acceleration response spectrum (Ishikari-EW)

付録 D 加速度応答が大きくなる長周期地震動による検討

本稿で用いた長周期地震動は, 加速度応答が小さいため不感帯機構による 加速度低減効果が得られなかった。加速度応答が大きくなるケースとして, 2016 年 6 月に国土交通省より公表された, 南海トラフ沿いの巨大地震による 長周期地震動への対策の中で提示されている設計用長周期地震動 10 波 (表層 地盤 No.2 を採用） 17) を用いた応答解析を行った。代表的な解析結果として $\mathrm{CH} 1, \mathrm{OS} 1$ の最大絶対加速度を Fig.A9 亿, 免震層変位最大值と上階絶対加速 度最大值の関係を Fig.A10 に示す。不感帯機構を用いたことで, 長周期地震 動に対しても加速度応答が低減していることを確認した。

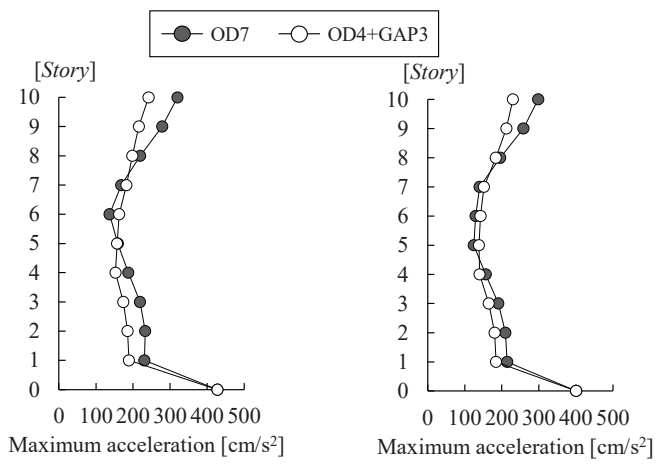

(a) $\mathrm{CH} 1$

(b) OS1

Fig.A9 Maximum response of acceleration

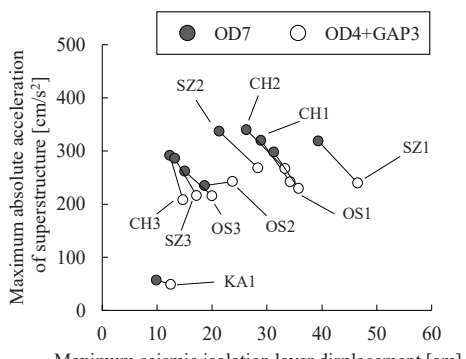

Maximum seismic isolation layer displacement $[\mathrm{cm}]$

Fig.A10 Relation of acceleration and displacement of seismic isolation layer 


\title{
SEISMIC RESPONSE CHARACTERISTICS OF SEISMICALLY ISOLATED BUILDING WITH DEAD ZONE MECHANISM CONNECTED TO OIL DAMPER
}

\author{
Kazuo YACHIUNE ${ }^{* 1}$, Akira SUZUKI ${ }^{* 2}$, Yuta SAITO*3, \\ Masaki TOKUNO ${ }^{* 2}$ and Masahito KOBAYASHI*4 \\ *1 Toda Corporation \\ *2 Toda Corporation, MEng. \\ ${ }^{* 3}$ Grad. Student, Graduate School of Science and Technology, Meiji Univ. \\ ${ }^{* 4}$ Prof., Dept. of Architecture, School of Science and Technology, Meiji Univ., Dr.Eng.
}

In recent years, there is concern about the occurrence of extreme ground motions that greatly exceed the amplitude levels and durations expected in conventional design level. Therefore, seismically isolated buildings are required to secure the seismic isolation performance for small earthquakes and to suppress the excessive displacement of the seismic isolation layer for extreme ground motions. As one of the effective means to meet the above requirements, in addition to an electromagnetic switching semi-active seismic isolation system, a cheaper and more reliable passive damper is being developed. Meanwhile, the authors have proposed a dead zone mechanism that is an accessory device connected to the existing oil damper.

When the relative displacement of seismic isolation layer is smaller than the set amplitude (medium and small earthquakes level), the dead zone mechanism only slides and no damping force is generated in the oil damper, and when the amplitude is larger than the set amplitude (extreme ground motions), this mechanism generates damping force and suppresses excessive displacement. Furthermore, one of the features of this mechanism is that it has a mechanism that automatically returns the rod to the original position after the earthquake. In this paper, we analyze the seismic response of seismically isolated buildings using the dead zone mechanism to understand the response characteristics.

1) When the publicly announced wave and pulse ground motions are used as input earthquakes, an oil damper with a dead zone mechanism is used in the seismic isolation building to ensure seismic isolation performance for small and medium earthquakes, while suppressing excessive displacement of the seismic isolation layer for extreme ground motions. It was confirmed that the desires effect of doing was obtained. In this analysis case, the most effective performance was shown when the dead zone width was set to $15 \mathrm{~cm}$.

2) When the long period ground motions is used as the input ground motions, the acceleration response of the GAP model is larger than that of the OD model, but the acceleration is small at about $100 \sim 200 \mathrm{~cm} / \mathrm{s}^{2}$, which is considered to be within the allowable range for seismic isolation.

3) It was confirmed that the automatic return spring in the dead zone mechanism automatically returns the rod in the mechanism to the neutral position at the end of the earthquake. Therefore, by automatically returning the dead zone mechanism to the automatic return spring in the dead zone mechanism, it is possible to maintain the structural performance assumed at the time of design even when multiple earthquakes occur in a short period of time.

4) In all earthquakes, when the seismic isolation layer displacement reaches the dead zone width, the absolute acceleration increase in the lower layer. The cause is considered to be a reaction force due to the elements of the dead zone mechanism contacting each other. The $1 / 3$ octave band analysis was applied to the time history waveform of the absolute response acceleration above the seismic isolation layer of each model. It was confirmed that the value was sufficiently smaller than the judgment value of the rank with the lowest anxiety level, compared with the evaluation curve in the anxiety level evaluation by Takahashi et al. Therefore, it was confirmed that the increase in acceleration response when the elements in the dead zone mechanism were in contact had little effect on the habitability. 